\title{
Data envelopment analysis and data mining to efficiency estimation and evaluation
}

\author{
Abdel Latef M. Anouze \\ Department of Management and Marketing, Qatar University, \\ Doha, Qatar, and \\ Imad Bou-Hamad \\ Suliman S. Olayan School of Business, American University of Beirut, \\ Beirut, Lebanon
}

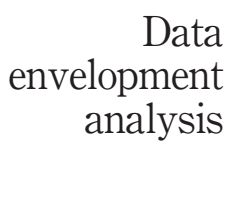

169

\begin{abstract}
Purpose - This paper aims to assess the application of seven statistical and data mining techniques to second-stage data envelopment analysis (DEA) for bank performance.

Design/methodology/approach - Different statistical and data mining techniques are used to secondstage DEA for bank performance as a part of an attempt to produce a powerful model for bank performance with effective predictive ability. The projected data mining tools are classification and regression trees (CART), conditional inference trees (CIT), random forest based on CART and CIT, bagging, artificial neural networks and their statistical counterpart, logistic regression.

Findings - The results showed that random forests and bagging outperform other methods in terms of predictive power.

Originality/value - This is the first study to assess the impact of environmental factors on banking performance in Middle East and North Africa countries.
\end{abstract}

Keywords Bank performance, Data envelopment analysis, MENA countries, Data mining tools

Paper type Research paper

\section{Introduction}

Sustainability is one of the concepts which has been associated with bank performance; therefore, assessing and predicting bank performance have become vital for managers when examining the suitability of their managerial decisions. Additionally, studying bank performance greatly facilitates measuring the success of decisions made by a bank as compared to those of its counterpart during the same period. Furthermore, it allows one to learn how to make better financial decisions that allocate financial resources in a more efficient manner. There is substantial body of published academic research that discusses different methods of evaluating bank performance; Berger and Humphrey (1997) grouped them into two main approaches, namely, parametric and nonparametric. The most popular parametric method is known as the stochastic frontier approach (SFA), whereas the most

(C) Abdel Latef M. Anouze and Imad Bou-Hamad. Published by Emerald Publishing Limited. This article is published under the Creative Commons Attribution (CC BY 4.0) licence. Anyone may reproduce, distribute, translate and create derivative works of this article (for both commercial and non-commercial purposes), subject to full attribution to the original publication and authors. The full terms of this licence may be seen at http://creativecommons.org/licences/by/4.0/legalcode

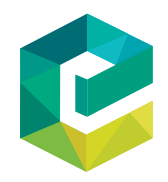

International Journal of Islamic and Middle Eastern Finance and Management Vol. 12 No. 2, 2019 pp. 169-190
Emerald Publishing Limited 1753-8394 DOI 10.1108/IMEFM-11-2017-0302 
IMEFM

12,2

popular nonparametric method is data envelopment analysis (DEA). Although using these methods could help researchers determine performance level, they are not sufficient to explain inefficiency or predict performance. Therefore, several studies, like that of Fethi and Pasiouras (2010), proposed a combination of measuring and explaining bank performance using DEA or SFA in the first stage to measure performance and regression models as a second stage to explain it. Casu and Molyneux (2003); Ariff and Can (2008) and San et al. (2011) used Tobit regression in particular to explain bank performance. Other researchers used different regression models to explain bank performance; Anouze (2010); Emrouznejad and Anouze (2010) and Bou-Hamad et al. (2017) used boosted generalized linear model, and Seol et al. (2007) used decision trees, whereas Azadeh et al. (2011) used the artificial neural networks (ANNs). On the other hand, Sun and Li (2008) and Wu and Hsu (2019) used decision tree techniques to introduce a multiple criteria decision-making method to determine suitable warning mechanisms of corporate financial failure or distress. Meanwhile, Lai et al. (2011) used DEA to develop an intellectual benchmarking knowledgebased system for benchmarking, performance evaluation and process improvement.

However, no comparison of methods used in second DEA stage has been made, and most of these studies aimed only to explain the factors affecting efficiency rather than predicting future efficiency of banks. Predicting bank performance is extremely important: bad performance may lead to bankruptcy, which negatively influences the economy of a country. Thus, conceiving a powerful predictive model for bank performance would be useful in avoiding or at least limiting such consequences. Therefore, this study proposes a comprehensive performance evaluation framework based on managerial, financial and macroeconomic indicators to predict bank performance. More specifically, seven predictive techniques, namely, classification and regression trees (CART), conditional inference trees (CIT), random forest based on CART (RFCART), random forest based on CIT (RF-CIT), bagging, ANNs and logistic regression (LR) are assessed when applied to second-stage DEA. This framework is applied to a data set of 151 banks from Middle East and North Africa (MENA) countries observed over a period of three years (2008-2010); hence, the data set contains 453 observations with 15 environmental variables (predictors). For predictive comparison among the used data mining methods, we used the overall accuracy, sensitivity, specificity and the areas under the ROC curve (AUC).

The following sections are organized as follows: Section 2 reviews the related literature and Section 3 describes DEA and data mining methods used. Section 4 describes the MENA banks data set. The experimental set up and model performance measures used in our comparison are described in Section 5. Finally, we present and discuss our results in Section 6, and we conclude in Section 7.

\section{Literature review}

Several authors investigated the influence of environmental conditions on bank performance. Linear regression analysis is one of the most popular statistical techniques used in performance measurement. However, in practice, researchers have used regression analysis for both prediction and explanation of a firms' performance level (Azen and Budescu, 2003; Courville and Thompson, 2001; Johnson and LeBreton, 2004; Pedhazur, 1997). The linear regression result is not particularly well suited, as it is a common nature of the environmental variables to be correlated (Grömping, 2007).

Hence, other approaches to investigating the impact of environmental variables on performance were proposed. Ray (1988) proposed using a two-stage method; the first stage consisted of measuring bank efficiency using DEA, while in the second stage, the obtained DEA efficiency score of each bank is regressed against selected environmental variables using SFA. Later on, Ray (1991) proposed using a regression analysis in which the environmental 
variables are regressed on efficiency scores rather than the SFA. The second stage method (two-stage analysis), which is the most common method used among researchers (Ariff and Can, 2008; Casu and Molyneux, 2003; San et al., 2011), is seen as a solution for the impact of variables that are not included in the initial DEA model. In addition, Fried et al. (2002) recommended using three-stage analysis; the first stage comprised computing the efficiency score using DEA model. Then the total slack of the input and output constraints, [i.e. $x-X \lambda \geq$ 0 and $Y \lambda-y \geq 0]$ which is the source of inefficiency, is considered to have three effects: managerial inefficiencies, environmental influences and measurement error (statistical noise). In the third stage, SFA is used to estimate values for these components. Estelle et al. (2010) proposed a different three-stage framework, and their results show that the one-stage model is unable to decompose the efficiency and environment effects, which point out the weak performance of the one-stage model.

Alternative powerful methods such as CART (Anouze, 2010; Emrouznejad and Anouze, 2010); Seol et al., 2007) and ANNs (Azadeh et al., 2011; Toloo et al., 2015; Hanafizadeh, et al., 2014) were considered to complement the classic statistical genetic methods.

\section{Data envelopment analysis and data mining methodology}

The framework starts with DEA computation of the performance of each bank, and the efficiency scores obtained are grouped accordingly into efficient banks (efficiency score of 1 , target $=1$ ) and inefficient banks (efficiency score less than one, target $=0$ ). This classified efficiency score is used as a target, while the environmental (exploratory) variables are used as inputs of data mining techniques. Figure 1 depicts our proposed framework.

In the following paragraphs, we briefly describe the DEA and the seven prediction techniques used in our study.

\subsection{Data envelopment analysis}

DEA is a non-parametric method developed by Charnes et al. (1978) to measure the performance of set decision-making units (DMUs) (Emrouznejad et al., 2008 and Emrouznejad and De Witte, 2010). The initial DEA models consider constant return to scale (CRS) which ignores the fact that different DMUs (banks) could be operating at different scales. To overcome this drawback, Banker et al. (1984) introduced variable returns to scale (VRS) model,

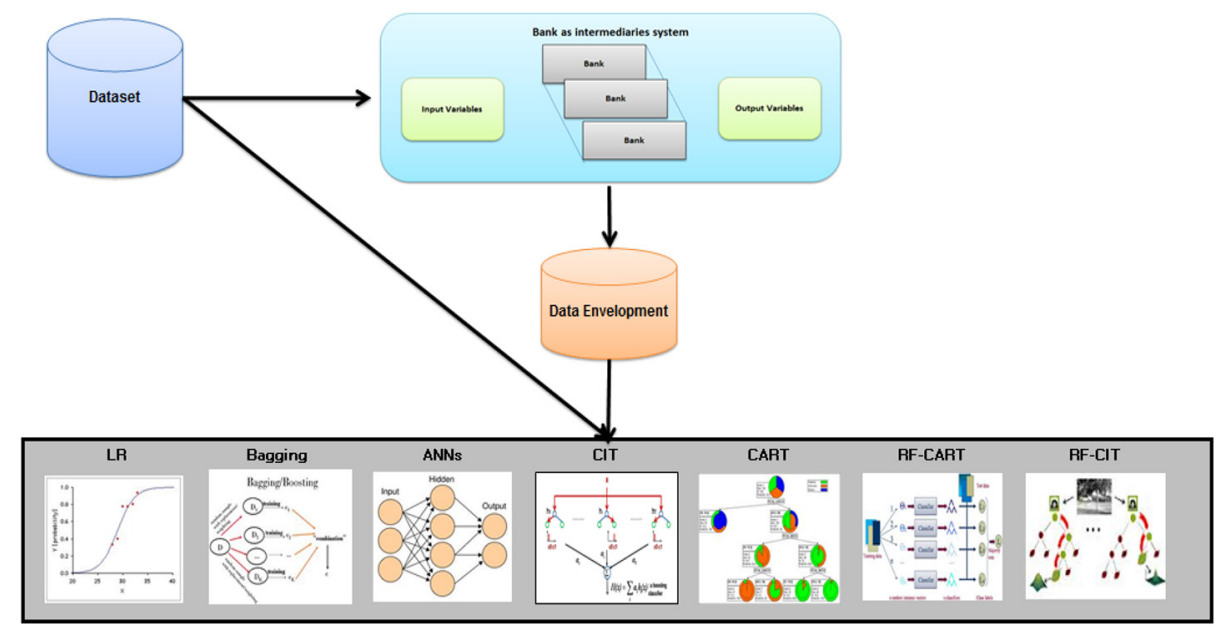

Figure 1. DEA/data mining methodology for MENA countries commercial banks 
IMEFM

12,2

which ensures that each bank is only benchmarked against banks of similar size. To introduce DEA-VRS model, assume there are $n$ banks $(\mathrm{a} j=1, \ldots, n)$ using $\mathrm{m}$ inputs $\left(x_{i j} i=1, \ldots, m\right)$ and producing s outputs $\left(y_{r j}, j=1, \ldots, s\right)$. DEA measures the technical efficiency of bank $\mathrm{j}_{0}$ compared to $n$ peer group of banks input and output. DEA formulation in Models (1a) assesses bank $\mathrm{j}_{\mathrm{j} 0}$ under VRS, where the efficiency of bank $\mathrm{j}_{0}$ is the optimal value of $\theta$. This model is described as input oriented. Similarly, an output-oriented DEA is defined in Model (1b) where the efficiency of bank $_{\mathrm{j} 0}$ is the optimal value of $1 / \varnothing$ (Thanassoulis, 2001).

Model 1a. Standard input-oriented DEA-VRS

\section{$\operatorname{Min} \theta$}

subject to

$$
\begin{gathered}
\sum_{j=1}^{n} \lambda_{j} x_{i j} \leq \theta x_{i j_{0}} \quad ; \forall i \\
\sum_{j=1}^{n} \lambda_{j} y_{r j} \geq y_{r j_{0}} \quad ; \forall r \\
\sum_{j=1}^{n} \lambda_{j}=1 \\
\lambda_{j} \geq 0 \quad ; \forall j, \theta \text { free }
\end{gathered}
$$

Model 1b. Standard output-oriented DEA-VRS

$\operatorname{Max} \varnothing$

subject to

$$
\begin{gathered}
\sum_{j=1}^{n} \lambda_{j} x_{i j} \leq x_{i j_{0}} \quad ; \forall i \\
\sum_{j=1}^{n} \lambda_{j} y_{r j} \geq h y_{r j_{0}} ; \forall r \\
\sum_{j=1}^{n} \lambda_{j}=1 \\
\lambda_{j} \geq 0 ; \forall j, \varnothing \text { free }
\end{gathered}
$$

To reach to CRS-DEA, one can remove $\sum_{j=1}^{n} \lambda_{j}=1$ constraint from the above models. 
However, DEA alone determines only the efficiency scores of each bank and does not account for the factors related to inefficiency; neither can it predict the performance of each bank (Emrouznejad and Anouze, 2010) nor account for flexible measures variables (Amirteimoori and Emrouznejad, 2011; Amirteimoori and Yan, 2014) and the uncertain nature of the future (Amirteimoori et al., 2013).

\subsection{Logistic regression}

LR is a generalization of linear regression (Hosmer and Lemeshow, 2000) used for predicting a dichotomous dependent variable (efficient, inefficient) or multi-class-dependent variables. LR assumes that the response variable is linear in the coefficients of the predictor variables. In this study, LR analysis is performed with financial and economic data related to bank performance to assess the independent effect of each factor. The specific form of a logistic model is as follows:

$$
\operatorname{probabilty}\left(\text { efficient } \mid x_{1}, \ldots, x_{m}\right)=\frac{1}{1+e^{-\left(\beta_{0+} \beta_{1} x_{1+\ldots+} \beta_{k} x_{m}\right)}}
$$

where $x_{1, \ldots,} x_{m}$ are $m$ explanatory variables. LR produces a simple probabilistic formula of classification, and this is its main advantage. However, the weakness is that LR cannot deal with the problems of non-linear and interactive effects of explanatory variables (Yeh and Lien, 2009).

\subsection{Classification and regression tree}

A classification and regression tree is a non-linear discrimination method that uses a set of independent variables to split a sample into progressively smaller subgroups. Tree-based methods have appeared with Morgan and Sonquist (1963). However, they gained their popularity through the major theoretical and practical contribution of Breiman et al. (1984). It was initially introduced as an alternative to parametric methods in discriminant and regression analysis and has been extended more recently to censored survival analysis (LeBlanc and Crowley, 1992; Bou-Hamad et al., 2009; Bou-Hamad et al., 2011). CART uses a recursive algorithm to split the data into classes (or nodes) based on logical if-then conditions on the explanatory variables. The splitting criteria of classification trees aim to find the best splitter explanatory variable portioning the parent node into two more homogenous children nodes. The algorithm starts with the root node (initial data set) and so on until growing a large tree. For classification trees, the goodness of the split is measured by the impurity function defined as follows:

$$
\Delta(s, t)=i(t)-p_{L} i\left(t_{L}\right)-p_{R} i\left(t_{R}\right)
$$

where $s$ is the candidate split of a variable $(v, t)$ the parent node, $i(t)$ the impurity of the node $t$ $p_{L}$ and $p_{R}$ the proportions of objects going to the left $\left(t_{L}\right)$ or right $\left(t_{R}\right)$ child nodes, respectively, and $i\left(t_{L}\right)$ and $i\left(t_{R}\right)$ their impurities. Several impurity measures have been proposed, and the most popular ones are the deviance and the Gini index. The impurity measure is defined as $i(t)=-\sum_{j=1}^{c} p_{j}(t) \ln \left(p_{j}(t)\right)$ for the deviance and $i(t)=1-\sum_{j=1}^{c}\left(p_{j}(t)\right)^{2}$ for the Gini index, where $p_{j}(t)$ is the proportion of objects in node $(t)$ that belong to the $j^{\text {th }}$ class of the $(C)$ classes present in the data set.

The growth of the tree can be continued until no further splits are possible. However, fully grown trees tend to over-fit the data, which is why a stopping criterion is needed. 
IMEFM

12,2

Breiman et al. (1984), proposed a pruning algorithm in which a large tree is grown then pruned back to produce a set of nested trees from which the final tree will be selected.

The main advantage of classification trees is the simplicity of interpreting their results. Another advantage is that classification trees do not require implicit assumptions as in the case of parametric models. Despite their advantages, decision trees suffer from instability (Breiman et al., 1984), where a small change in the training data may have a major impact on the predictive ability of the tree.

\subsection{Conditional inference trees}

Unlike CART where its splitting criterion is based on impurity reduction, the CIT recently proposed by Hothorn et al. (2006b) use a splitting criterion based on multiplicity-adjusted conditional tests (Hothorn et al., 2006a). For any node, the splitting procedure consists of conducting a global permutation test of no association between any predictor variable and the response within the node. If the global hypothesis of no association is not rejected, the node is not split and is considered a terminal node. Otherwise, for each predictor, an individual null hypothesis of no association with the response will be conducted. The predictor with the lowest $p$-value is selected for splitting. In CIT, pruning is not required as the trees stop growing when the split is not statistically significant.

\subsection{Bagging}

A single tree is unstable in the sense that small perturbations in its training set may result in changes in its predictions (Breiman, 1996). Using ensemble methods such as bagging and random forests often produces better performances than using a single tree. Bagging is a bootstrap ensemble method introduced by Breiman (1996). It can be used with many classification methods and regression methods to reduce the variance associated with prediction and therefore improve the prediction process (Sutton, 2005). Hence, it consists of averaging the fitted values of the response variable of many trees built with bootstrapped samples from the original data. Basically, it trains each classifier on a randomly drawn training set; each classifier's training set consists of same number of banks randomly drawn from the original training set, with an equal probability of drawing any given bank. These samples are drawn with replacement so that some banks may be selected multiple times, while others may not be selected at all. As a result, each classifier could return a higher test set error than a classifier using all of the data (Kim, 2006). However; when these classifiers are combined (typically by voting), the resulting ensemble produces a lower error on the test set than a single classifier. Bagging has been found to be the simplest algorithm that helps in reducing variance and improving unstable classifiers in accuracy (Breiman, 1996). It also enhances accuracy when random features are used and can help avoid overfitting. However, the disadvantage of bagging is that bagged trees are not as easily interpretable as a single tree (Zhu, 2010).

\subsection{Random forests}

Breiman (2001) originally introduced the random forest as an ensemble of CART trees (RFCART). This method gives a prediction based on the majority voting (the case of classification) or averaging (the case of regression) predictions made by each tree in the ensemble using some input data (Antipov and Pokryshevskaya, 2012). In this sense, it is similar to the bagging technique, and it combines many individual decision trees to provide a final prediction. However, the key difference between them is that bagging uses an exhaustive search of all the explanatory variables to find the best split, while RF uses a randomly selected set of explanatory variables at this step. Recently, Strobl et al. (2007) 
developed a random forest based on conditional inference trees (RF-CIT). The general method of both RF-CART and RF-CIT can be outlined as follows:

- Draw B bootstrap samples from the data,

- Grow a tree for each bootstrap sample. At each node, select at random $\mathrm{k}$ out of $\mathrm{m}$ covariates on which to base the decision at that node.

- Each tree is fully grown and not pruned. The splitting is stopped when a minimum node size is reached.

$\mathrm{RF}$ suffers from the same problem of interpretation as bagging does. However, several techniques have been developed for RF to allow for interpretation. The most useful one is the variable importance; the common and frequently used variable importance measure is the permutation-based mean decrease in accuracy (Breiman, 2001). This measure allows researchers to identify a set of important variables that can potentially affect the dependent variable.

\subsection{Artificial neural networks}

ANNs are one of the most commonly used data mining models for prediction. An ANN is inspired by the structure of biological neural networks where neurons are interconnected and learn from experience. Neural networks are composed of nodes (neurons) arranged in layers that are fully connected to the preceding layer via a system of weights. Numerous different neural network architectures have been studied. However, the most successful applications of neural networks have been multilayer feed forward networks. These are networks in which there is an input layer, one or more hidden layers and an output layer. The input layer is where the input features are fed and forwarded to the hidden layer, which is again forwarded to the output layer.

The output of a hidden layer node is computed in the following manner. First, a weighted sum of inputs is computed and then a transfer function is applied to this sum. More specifically, for a set of input values, $x_{1}, x_{2}, \ldots, x_{m}$, the output of node $j$ is computed by taking the weighted sum $\theta_{j}+\sum_{i=1}^{m} w_{i j} x_{i}$, where $\theta_{j}, w_{1 j}, \ldots, w_{m j}$ are weights that are initially set randomly and adjusted as the network learns. The next step is to apply a transfer function $g$ to this sum. A transfer function is a monotone function. The most popular transfer function is the logistic function $g(s)=1 /\left(1+e^{-s}\right)$. Finally, the output layer obtains input values from the hidden layer and the same transfer function is applied to create the output (Shmueli et al., 2010, pp. 222-229).

The common algorithm used to estimate and update the weights is the back-propagation (Rumelhart et al., 1986). However, this algorithm suffers from a low learning speed (Castillo et al., 2006). Many alternatives have been proposed to increase the learning speed. One of them is a general quasi-Newton optimization procedure, the Broyden-Fletcher-GoldfarbShanno algorithm that is used in this paper.

\section{Data description}

The proposed methodology is applied to a sample of banks operating in MENA countries over the period of 2008-2010. The period after 2011 was witness an Arabic Spring movement that impacted the performance of banking sector in these countries; therefore, these years were excluded to avoid any up-normal variation in bank performance. The total number of banks operating in MENA countries over the selected period was 535 banks, however due to data availability only 151 banks (Appendix A) are included. The sample includes data from 
IMEFM

12,2

176

Lebanon (27 banks); Egypt (21); United Arab Emirates (18); Bahrain; Israel and Jordan (13 banks each); Saudi Arabia (11); Oman (7); Qatar and Tunisia, (6 banks each); Iran and Kuwait (5 banks each); Algeria (2) and Libya; Morocco; Yemen and Palestine (1 bank each). Figure 2 illustrates their share of assets.

Although our sample consists of banks from various countries with differing accounting regulations, we believe the accounting data are comparable across the whole sample, as the financial statements data optioned from Bankscope are reported in a unified global format.

\subsection{Data envelopment analysis input and output variables}

In general, different set of input and output variables were used in various studies. A debatable concern usually occurs when it comes to classifying a variable as either an input or an output due to varying definitions. There are three main approaches used as a base to select and classify the input and output variables: production, intermediate and value-added approach. Other researchers used a mix approaches. The first approach popular in branches efficiency studies was that bank is treated as a vendor who use labor, capital and equipment to produce various number of deposits and loans transactions. The second approach treats banks as intermediaries between savers and investors, hence variables such as labor or labor cost and deposits and assets were frequently used as inputs and variables like loans, securities and investments were frequently used as outputs.

In this study, for the purpose of measuring bank performance and comparing different data mining techniques in predicting the performance, an in-depth analysis of previously published literature was conducted to select the most popular input and output variables. A total of 204 published were reviewed and analyzed in term of used inputs, output and environmental variables. In term of DEA input and output variables, most of the reviewed literature relied on bank's balance sheet. Figure 3 illustrates the most used input variables, whereas Figure 4 illustrates the most used DEA output variables and Table II illustrates the most used environmental variables and the used statistical test to study the impact of the environmental variables on bank performance.

Figure 3 shows the most popular DEA input variables are fixed assets, personnel expenses and number of employees, operational (interest) expense, overhead expenses, number of branches, premises and deposits. However, due to data availability and high correlation between personnel expenses and number of employees; therefore, personnel expenses with fixed assets, deposit and equity are selected as a DEA input variable.

Figure 2.

Share of assets, MENA countries commercial banks

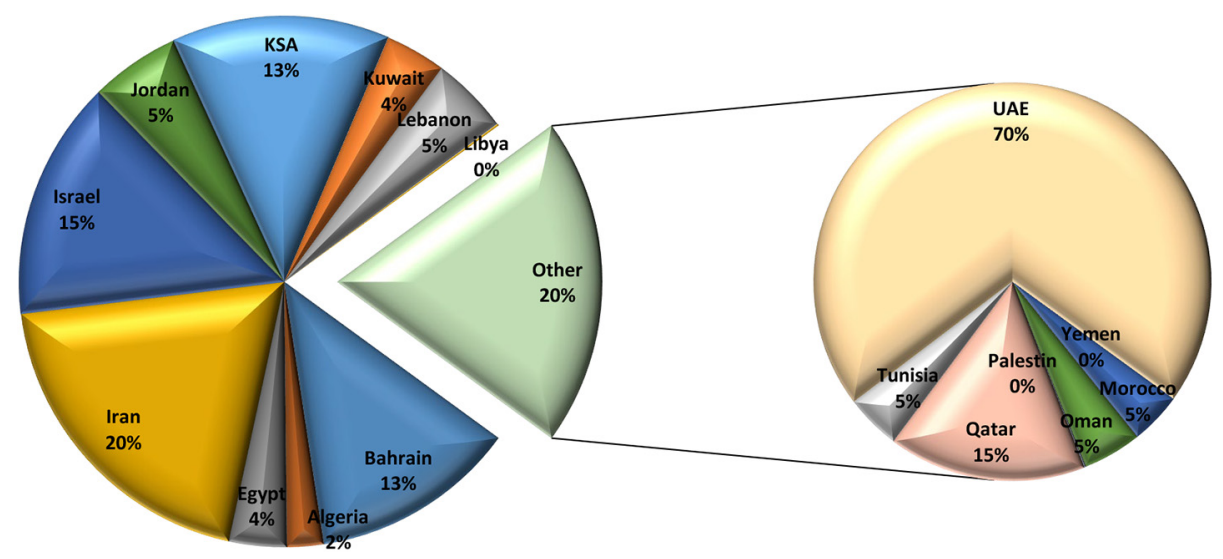


On the other hand, Figure 4 shows the most popular DEA output variables that extracted from the reviewed literature.

Figure 4 shows that loans is the most used output variable followed by investment, other earning assets, net commission, profit and off-balance sheet items. However, due to data availability the following outputs are selected loans, net income (profit), off-balance sheet and liquid assets.

A brief statistical descriptive of DEA input and output variables are presented in Table I. On the other hand, Table III describes the 15 environmental variables considered for the second stage, as inputs to data mining algorithms.

Table I shows that DEA model consists of five inputs and four outputs. These variables vary over the study period: the minimum value of fixed assets, which is one of the inputs, is US $\$ 0.16 \mathrm{~m}$, whereas the maximum value is US $\$ 2,424.24 \mathrm{~m}$, with an average of US $\$ 143.83 \mathrm{~m}$ and standard deviation of US\$305.39m. In terms of loans, which are output variables, the minimum loan is US\$1.28m, and the maximum value is US\$58,487.64m, with an average of US\$6,052.46m and standard deviation of US\$9,702.11m. Therefore, as DEA models are sensitive to observations, it is likely to find significant levels of variation in the efficiencies as well.

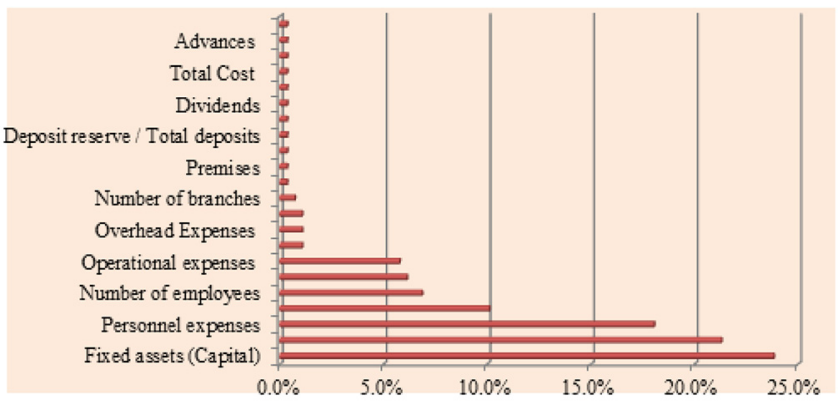

Source: Developed by researchers

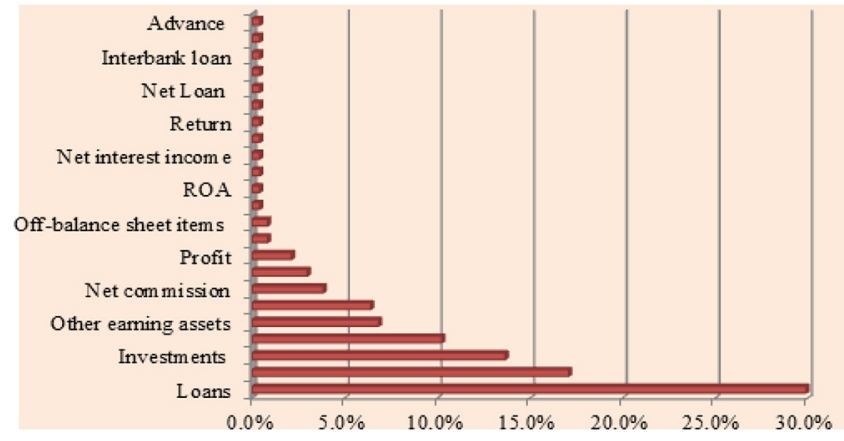

Source: Developed by researchers envelopment analysis

Figure 3. Summary of used input variables in the reviewed literature

Figure 4.

Summary of used output variables in the reviewed literature 
IMEFM

12,2

\section{8}

\subsection{Determinants of bank efficiency: select data mining input variables}

Although, measuring bank efficiency score can vary according to managerial decisions, the impact of environmental variables has been highlighted by previous research because of its effect on these decisions. Table II summarizes part of the previously published studies in this field along with the statistical methods used to investigate the impact of environment variables on bank performance.

Table II presents key findings of previous studies that investigated the impact of different exogenous variables on banks efficiency and the used statistical test. It is clear from this table that these studies used different environmental variables, and the majority of researchers used regression analysis. Few of them used other techniques such as classification and regression and data mining techniques. Introducing such methods to the study of bank performance was motivated by the need to avoid some of the critical problems in regression analysis by avoiding parametric assumptions, reducing dimensionality of the model and removing the redundant variables, which is in favor of the model's performance. Moreover, selecting the most important variables with good predictive capacities will allow us to interpret the parameter estimates easily due to a plausible reduction of multicollinearity. Based on Table II and data availability, Table III illustrates the statistical description of the selected environmental variables.

\section{Experimental setup}

This section describes the data used for training and testing the model, the adjustable parameters for each data mining technique and the predictive performance measures used.

\subsection{Data partition and parameters}

Using the statistical programming language $R$, which is widely used among statisticians, all predictor variables are included as inputs, and the efficiency class $(0$ or 1$)$ obtained from DEA is also included as output. Then the initial data set is partitioned into training and validation data sets. The training data set contains all of the bank data over the two years 2008 and 2009, while the data set of 2010 is used for testing. The adjustable parameters of each class have been set. The bagging and the two types of random forests (RF-CART and RF-CIT) are built with 50 bootstrap samples. For neural networks, one hidden layer with five neurons is used. The splitting criterion used in CART is the deviance. The minimum number of observations in a node is fixed to 10. For CIT, the significance level of the permutation tests is set to 5 per cent. The deletion or inclusion of an explanatory variable in the logistic model is based on Akaike's information criterion.

\begin{tabular}{lrrrc}
\hline Description & Average & \multicolumn{1}{c}{ SD } & Maximum & Minimum \\
\hline Inputs & & & & \\
Fixed assets & 143.83 & 305.39 & $2,424.24$ & 0.16 \\
Deposits & $8,628.96$ & $12,543.11$ & $67,599.47$ & 2.11 \\
Equity & $1,115.05$ & $1,675.85$ & $8,229.41$ & 4.95 \\
Interest expense & 285.25 & 404.57 & $2,569.13$ & 0.12 \\
Personnel expenses & 88.06 & 174.25 & $1,252.50$ & 0 \\
Outputs & & & & \\
Loans & $6,052.46$ & $9,702.11$ & $58,487.64$ & 1.28 \\
Net income & 140.28 & 286.27 & $1,804.59$ & 0 \\
Off-balance sheet & $3,522.14$ & $7,217.32$ & $68,429.57$ & 0 \\
Liquid assets & $2,457.64$ & $3,603.58$ & $26,637.08$ & 2.31 \\
\hline
\end{tabular}

Table I.

Statistical descriptive of input and output variables (US\$m)
Liquid assets
2.11 


\begin{tabular}{|c|c|c|c|c|c|}
\hline & Study & $\begin{array}{l}\text { Study } \\
\text { period }\end{array}$ & Method used & Environmental variables & envelopment \\
\hline 1 & $\begin{array}{l}\text { Fernandes, Stasinakis } \\
\text { and Bardarova (2018) }\end{array}$ & $2007-2014$ & $\begin{array}{l}\text { Double-bootstrapped } \\
\text { truncated regression } \\
\text { (DBTR) }\end{array}$ & $\begin{array}{l}\text { Capital risk, liquidity risk, banks' profitability, } \\
\text { Credit risk, Size (log of total assets), GDP and } \\
\text { inflation }\end{array}$ & lysis \\
\hline 2 & Nguyen (2018) & $2007-2014$ & $\begin{array}{l}\text { Ordinary least squares } \\
(\mathrm{OLS})\end{array}$ & $\begin{array}{l}\text { Bank diversification (modified Herfindahl- } \\
\text { Hirschman Index, HHI): asset diversification } \\
\text { (ADIV), funding diversification (FDIV), and income } \\
\text { diversification (IDIV). Bank size, Ownership and }\end{array}$ & 179 \\
\hline 3 & $\begin{array}{l}\text { Miah and Uddin } \\
(2017)\end{array}$ & $2005-2014$ & $\begin{array}{l}\text { Ordinary least squares } \\
(\mathrm{OLS})\end{array}$ & $\begin{array}{l}\text { Regulation } \\
\text { Ratio of liquid asset to deposit and short-term } \\
\text { funding and z-score as a measure of banks } \\
\text { stability, business orientation, bank's size, earning } \\
\text { assets, and equity buffer }\end{array}$ & \\
\hline 4 & $\begin{array}{l}\text { Tana and Anchor } \\
(2017)\end{array}$ & $2003-2013$ & $\begin{array}{l}\text { Bootstrapped } \\
\text { truncated regression }\end{array}$ & $\begin{array}{l}\text { Risk variables: Credit risk, Liquidity risk, Capital } \\
\text { risk, Insolvency risk } \\
\text { Other bank-specific variables: Bank size, Bank } \\
\text { diversification } \\
\text { Bank profitability: Return on Assets, } \\
\text { Industry-specific variables: Banking sector } \\
\text { competition, Banking sector development, Stock } \\
\text { market development, } \\
\text { Macroeconomic environment: Inflation and GDP } \\
\text { growth rate }\end{array}$ & \\
\hline 5 & $\begin{array}{l}\text { Singh and Thaker } \\
(2016)\end{array}$ & $2008-2012$ & $\begin{array}{l}\text { Descriptive tests/ } \\
\text { Analysis }\end{array}$ & Bank ownership groups and size & \\
\hline 6 & Zha, et al (2016) & $2008-2012$ & Wilcoxon test & Ownership structure & \\
\hline 7 & $\begin{array}{l}\text { Sufian and } \\
\text { Kamarudin (2015) }\end{array}$ & $2006-2011$ & $\begin{array}{l}\text { Ordinary least squares } \\
\text { (OLS) }\end{array}$ & $\begin{array}{l}\text { Total assets (size of bank); Loan loss reserve to } \\
\text { gross loan (asset quality); Equity to total assets } \\
\text { (capitalization); Bank's deposit over total deposit } \\
\text { (market power); Total loan over total assets } \\
\text { (liquidity); Non-interest expense over total assets } \\
\text { (management quality); Gross domestic product } \\
\text { (gross domestic product); Customer prices index } \\
\text { (inflation); Domestic Islamic bank; Number of the } \\
\text { bank; and Number of the year }\end{array}$ & \\
\hline 8 & Shawtari, et al. (2015) & 1996-2011 & $\begin{array}{l}\text { Ordinary least squares } \\
\text { (OLS) }\end{array}$ & $\begin{array}{l}\text { GDP; inflation; Market concentration; Total loan/ } \\
\text { Total Assets; Non-interest income/ None finance } \\
\text { income; Loan loss provision/ Total loans; Net } \\
\text { Income/ Total Assets; Net income/Total assets; Size }\end{array}$ & \\
\hline 9 & $\begin{array}{l}\text { Yadav and Katib } \\
(2015)\end{array}$ & 2006-2012 & $\begin{array}{l}\text { Ordinary least squares } \\
\text { (OLS) }\end{array}$ & $\begin{array}{l}\text { Loans Intensity; Total Assets; Loan Loss } \\
\text { Provision/ Total Loans; Non-Interest Income/ Total } \\
\text { Assets, bank's capitalization; and ROA }\end{array}$ & \\
\hline 10 & Wanke, et al (2015) & 1996-2011 & OLS regression & Ownership, Size; Merger and Acquisition & \\
\hline 11 & Mesa, et al (2014) & 2010 & $t$-test & $\begin{array}{l}\text { Size; Competition; Diversification; Capital } \\
\text { Structure; Funding ratio; ROA; Human resources } \\
\text { strategy }\end{array}$ & \\
\hline 13 & San-Jose, et al (2014) & $2000-2011$ & Tobit regression & Bank operating style (saving, commercial) & \\
\hline 14 & Chan, et al. (2014) & $2001-2008$ & Tobit regression & Risk & \\
\hline 15 & Hou et al. (2014) & $2007-2011$ & Truncated regression & Market structure & \\
\hline 16 & Rosman et al. (2013) & $2007-2010$ & Tobit regression & $\begin{array}{l}\text { Return on asset, Total assets (log), Equity/ Total } \\
\text { asset, and Loan loss provision/ Net interest revenue }\end{array}$ & \\
\hline 17 & Akin, et al. (2013) & $2007-2010$ & Topsis and Electre III & Ownership & \\
\hline 18 & $\begin{array}{l}\text { Chortareas, et al. } \\
\text { (2013) }\end{array}$ & $2001-2009$ & Truncated regression & Financial freedom & $\begin{array}{l}\text { Summary of } \\
\text { environment variables }\end{array}$ \\
\hline 19 & Matthews (2013) & $2007-2008$ & & Risk management & and the used \\
\hline & & & & (continued) & statistical methods \\
\hline
\end{tabular}




\begin{tabular}{|c|c|c|c|c|}
\hline & Study & $\begin{array}{l}\text { Study } \\
\text { period }\end{array}$ & Method used & Environmental variables \\
\hline 20 & $\begin{array}{l}\text { Elyasiani and Wang } \\
\text { (2012) }\end{array}$ & 1997-2007 & Regression & $\begin{array}{l}\text { Total assets (log); Noninterest income/ Total } \\
\text { income; Total liability/ Total assets; Net income/ } \\
\text { Total assets; Intangible assets/ Total assets; Bank } \\
\text { income diversification }\end{array}$ \\
\hline 21 & Yang (2012) & 2009 & Tobit regression & $\begin{array}{l}\text { ROA; Cost to income; Non-performing loan ratio; } \\
\text { Total assets; Privatization; Private banks; } \\
\text { Financial holding banks }\end{array}$ \\
\hline 22 & $\begin{array}{l}\text { Zhang and Matthews } \\
\text { (2012) }\end{array}$ & 1992-2007 & Truncated regression & $\begin{array}{l}\text { Ownership; Market shares; Size (total assets, log); } \\
\text { Diversification: Noninterest income/ total assets. } \\
\text { Cost/ income ratio; GDP growth rate }\end{array}$ \\
\hline 23 & Assaf et al. (2011) & 1999-2007 & $\begin{array}{l}\text { Bootstrapped } \\
\text { truncated regression }\end{array}$ & $\begin{array}{l}\text { Total assets (log); Net profit margin; Liquidity; } \\
\text { Payout ratio; Ownership }\end{array}$ \\
\hline 24 & $\begin{array}{l}\text { Chronopoulos et al. } \\
\text { (2011) }\end{array}$ & $2001-2007$ & Regression & $\begin{array}{l}\text { Index of income diversification; Total assets (log); } \\
\text { Equity to total assets ratio; Total loans to total } \\
\text { assets ratio; Total loans to total deposits ratio; } \\
\text { ROA; Domestic credit to the private sector/GDP; } \\
\text { Herfindah index; Banking assets controlled by } \\
\text { foreign investors; GDP per capita; GDP growth; } \\
\text { Index of financial freedom; Inflation rate }\end{array}$ \\
\hline 25 & Epure et al. (2011) & 1998-2006 & Cluster analysis & $\begin{array}{l}\text { ATMs/ Total Assets; No. of Branches/ Total } \\
\text { Assets/ Liabilities; Interest Margin/No. of } \\
\text { Employees; ROA; ROE }\end{array}$ \\
\hline 26 & Gardener et al. (2011) & 1998-2004 & Tobit regression & $\begin{array}{l}\text { Size; Profit; Capital; Bank private credit; } \\
\text { Regulation; Economic growth; Inflation; Country- } \\
\text { level of state; Ownership }\end{array}$ \\
\hline 27 & Luo et al. (2011) & 1999-2008 & Regression & $\begin{array}{l}\text { Ownership; ROA; Time trend (t); GDP; Ratio of } \\
\text { loan loss reserves to total loans; Equity to total } \\
\text { asset }\end{array}$ \\
\hline 28 & Rezvanian et al. (2011) & 1998-2006 & Tobit regression & $\begin{array}{l}\text { Profitability: ROA; ROE; Capitalization: bank } \\
\text { equity capital to total assets; Size: total assets (log); } \\
\text { Ownership; Regulatory quality: An indicator of the } \\
\text { regulatory quality; Economic development: GDP }\end{array}$ \\
\hline 29 & $\begin{array}{l}\text { Shyu and Chiang } \\
\text { (2012) }\end{array}$ & $2007-2008$ & Regression & $\begin{array}{l}\text { Economic growth rate; CPI; Branch floor area; } \\
\text { Years of operation; Loan amount }\end{array}$ \\
\hline 30 & Tanna et al. (2011) & $2001-2006$ & Regression & $\begin{array}{l}\text { Natural logarithm of number of board directors; } \\
\text { Non-executive directors/total number of board } \\
\text { directors; Natural logarithm of bank total assets; } \\
\text { Equity/ total assets; Time trend }\end{array}$ \\
\hline 31 & $\begin{array}{l}\text { Burki and Niazi } \\
(2010)\end{array}$ & $1991-2000$ & Tobit regression & $\begin{array}{l}\text { Real assets (log); Interest income to earning assets; } \\
\text { Loans to deposits ratio; Foreign bank; Private } \\
\text { bank; Nonperforming loans; Number of bank } \\
\text { branches (log) }\end{array}$ \\
\hline 32 & $\begin{array}{l}\text { Emrouznejad and } \\
\text { Anouze (2010) }\end{array}$ & $1997-2003$ & C\&R tree & $\begin{array}{l}\text { Country; Operational style; Size; Number of } \\
\text { branches; P/E; Established date; Number of } \\
\text { employees; Price book value; Beta; Capital } \\
\text { structure; Population; Market share }\end{array}$ \\
\hline 33 & $\begin{array}{l}\text { Fiordelisi and } \\
\text { Molyneux (2010) }\end{array}$ & 1995-2002 & Regression & $\begin{array}{l}\text { Market adjusted returns for listed banks; Ratio } \\
\text { between economic value added and the invested } \\
\text { capital at time ( } t)\end{array}$ \\
\hline 34 & $\begin{array}{l}\text { Hermes and Nhung } \\
(2010)\end{array}$ & $1991-2000$ & Regression & $\begin{array}{l}\text { Financial liberalization; Density of Demand; GDP } \\
\text { growth; Inflation rate; Capital to asset ratio; ROE; } \\
\text { Total loans to deposits ratio }\end{array}$ \\
\hline 35 & Staub et al. (2010) & $2000-2007$ & Tobit regression & $\begin{array}{l}\text { Size; Non-performing loans; Market Share; Equity } \\
\text { over assets ratio; Ownership }\end{array}$ \\
\hline
\end{tabular}

Table II.

\section{0}

\section{Yang (2012)}

22 Zhang and Matthews (2012)

23 Assaf et al. (2011)

Chronopoulos et (2011)

Shyu and Chiang (2012)

30 Tanna et al. (2011)

Burki and Niazi (2010)

Emrouznejad and Anouze (2010)

Fiordelisi an

Hermes and Nhung (2010)

.




\begin{tabular}{|c|c|c|c|c|c|}
\hline Input variables & Average & Stand & Maximum & Minimum & \\
\hline \multicolumn{6}{|l|}{ Country } \\
\hline Loan loss reserve/gross loans & 6.85 & 8.49 & 67.63 & 0 & \\
\hline Loan loss provision/net interest reserve & 25.89 & 66.59 & 925.81 & (150.00) & \\
\hline Equity/total assets & 12.70 & 9.47 & 91.23 & 0.72 & \\
\hline Equity/net loans & 33.87 & 62.42 & 987.42 & 1.10 & \\
\hline Equity/liabilities & 18.35 & 38.54 & 502.70 & 0 & 181 \\
\hline Net interest margin & 3.19 & 1.44 & 9.39 & (1.57) & \\
\hline Return on average assets (ROAA) & 1.14 & 1.72 & 5.37 & (15.47) & \\
\hline Return on average equity (ROAE) & 9.89 & 15.64 & 60.99 & (155.44) & \\
\hline Cost to income ratio & 52.71 & 45.70 & 613.43 & 0 & \\
\hline Recurring earning power & 2.03 & 1.49 & 6.73 & (11.12) & \\
\hline Interbank ratio & 191.77 & 223.22 & 983.42 & 0 & \\
\hline Net loans/total assets & 50.87 & 18.89 & 99.52 & 5.98 & \\
\hline Net loans/deposit and short term funding & 71.55 & 67.89 & 959.10 & 0 & \\
\hline Liquid assets/total deposit and borrowing & 28.41 & 24.73 & 298.92 & 0 & \\
\hline
\end{tabular}

Notes: Country: organized in alphabetic order;

Asset quality

Loan loss reserve/gross loans: indicates how much of the total portfolio has been provided for but not charged off. The higher the ratio the poorer will be the quality of the loan portfolio;

Loan loss provision/net interest revenue: presents the relationship between provisions in the profit and loss account and the interest income over the same period. Ideally, this ratio should be as low as possible;

Capital

Equity/total assets: measures the ability of a bank to withstand losses. A declining trend in this ratio may signal increased risk exposure and possibly capital adequacy problem;

Equity/net loans: measures the equity cushion available to absorb losses on the loan book;

Equity/liabilities: is another way of looking at the equity funding of the balance sheet and is another way of looking at capital adequacy;

Operations

Net interest margin: is the net interest income expressed as a percentage of earning assets. The higher this ratio, the cheaper the funding or the higher the margin the bank is commanding. Higher margins and profitability are desirable as long as the asset quality is being maintained;

Return on average assets (ROAA)

Return on average equity (ROAE)

Cost to income ratio: measures the overheads or costs of running the bank. It is a measure of efficiency although if the lending margins in a particular country are very high then the ratio will improve as a result. It can be distorted by high net income from associates or volatile trading income; Recurring earning power: measure of after tax profits adding back provisions for bad debts as a percentage of total assets. Effectively, this is a return on assets performance measurement without deducting provisions;

Liquidity

Interbank ratio: is money lent to other banks divided by money borrowed from other banks. If this ratio is greater than 100 , then it indicates the bank is net placer rather than a borrower of funds in the market place, and more liquid;

Net loans/total assets: indicates what percentage of bank assets is tied up in loans. The higher this ratio the less liquid the bank will be;

Net loans/customer and short-term funding: high figure denotes lower liquidity;

Liquid assets/total deposit and borrowing: amount of liquid assets available to borrower and depositors

Table III.

Statistical description of the environmental factors 


\section{IMEFM}

12,2

\section{2}

\subsection{Performance criteria}

We used some popular measures of prediction performance frequently used in the literature. These measures are overall accuracy, sensitivity, specificity and the area under the ROC curve (AUC). Accuracy is the total number of banks (either efficient or inefficient) correctly classified over the total number of banks in the sample. Sensitivity is the total number of efficient banks correctly classified divided by the total number of efficient banks in the sample. Specificity is the total number of inefficient banks correctly classified divided by the total number of inefficient banks in the sample.

The above performance measures (accuracy, sensitivity and specificity) depend on a certain cutoff value for labeling the class, which is in general set at 0.5. However, AUC is considered as a better measure of overall performance and does not depend on any specific classification cutoff (Ling et al., 2003). Thus, the higher the AUC, the better a classifier performs.

\section{Results and discussion}

\subsection{First and second stage results}

To provide an efficiency trend of MENA countries' commercial banks, one meta-frontier (common- frontier) approach is computed for all banks in all countries. This approach provides variations in the efficiency of banks over both time and space, which would not be the case if a separate frontier for each year were computed. Output and input-oriented DEAVRS models are computed to measure the efficiency score of each bank.

Table IV shows that the overall average efficiency score is stable around 88 per cent over the study period for all banks. This suggests that by adopting best practices, MENA commercial banks can overall increase their outputs (without reducing any sources) or reduce their inputs (without losing any of their outputs) by approximately 11 to 13 per cent (i.e. $100-89$ per cent and $100-87$ per cent). However, the potential increment in outputs from adopting best practices varies from bank to bank. In general, MENA commercial banks have the scope of producing 1.14 times (i.e. $\frac{1}{0.87}$ ) as many outputs from the same level of inputs.

Furthermore, to measure bank efficiency across countries, the efficiency score for all banks is aggregated at country level to get the annual average efficiency scores for each country's commercial banks. Figure 5 illustrates the results.

Figure 5 shows the Algerian, Libyan and Yemen commercial banks outperform other countries banks. On the other hand, Jordanian and Lebanese commercial banks performed badly during the study period. The first stage results show the differences in inefficiency among banks in the 17 MENA countries. In this stage, the DEA results are classified into two groups, namely, efficient group (score of 1) and inefficient group (score of 0). This grouping is used as a target variable in each predictive technique. The classification or prediction performances of these techniques are presented in Table $\mathrm{V}$ based on the testing data set. It is seen that CIT outperforms the other techniques on sensitivity; however, it produced the lowest overall accuracy ( 67.55 per cent). RF-CART and bagging show the best overall performance with AUC of 0.9293 and 0.9221 , respectively. Moreover, their estimated AUCs exhibit the lowest standard errors (S.E.).

Table IV. Summary of banks efficiency scores

\begin{tabular}{lcccccc}
\hline & \multicolumn{3}{c}{ VRS input-oriented } & \multicolumn{3}{c}{ VRS output-oriented } \\
& 2010 & 2009 & 2008 & 2010 & 2009 & 2008 \\
\hline Average & 0.87 & 0.88 & 0.89 & 0.87 & 0.88 & 0.89 \\
Standard division & 0.15 & 0.15 & 0.14 & 0.16 & 0.15 & 0.14 \\
Number of efficient banks & 57 & 57 & 64 & 57 & 57 & 64 \\
\hline
\end{tabular}


Aside from the numerical measures, the graphs in Figure 6 highlight the comparison between the methods (classifiers) based on ROC curves. The ROC curve is useful for visualizing the overall performance of a classifier. It maps the sensitivity against 1 - specificity. The closer the curve is to the upper left corner, the higher the performance of the classifier. Figure 6 clearly shows that RF and bagging exhibit highest performance, whereas CART, CIT and ANN exhibit the poorest performance. Thus, RF and bagging could be potentially helpful tools for predicting bank performance. However, knowing what factors affect bank performance in MENA countries might be of interest to practitioners. Therefore, RF technique is used to determine the predictors' importance in the process of predicting bank efficiency

\subsection{Sensitivity analysis}

For robustness purposes, we re-estimate the second-stage analysis using linear regression model using the same variables. The justification for carrying out this additional analysis is to compare the result of the best performs data mining techniques with the traditional wellknown regression technique. The result of this comparison is reported in Table VI, which overall appear to corroborate the key findings reported in Table V and Figure 7. Specifically, we continue to find that both $\mathrm{RF}$ and bagging techniques outperform the regression test. It is worth to note that regression test (LR) shows competitive performance with CART and RFCIT on overall accuracy and specificity, but it outperforms them on sensitivity.

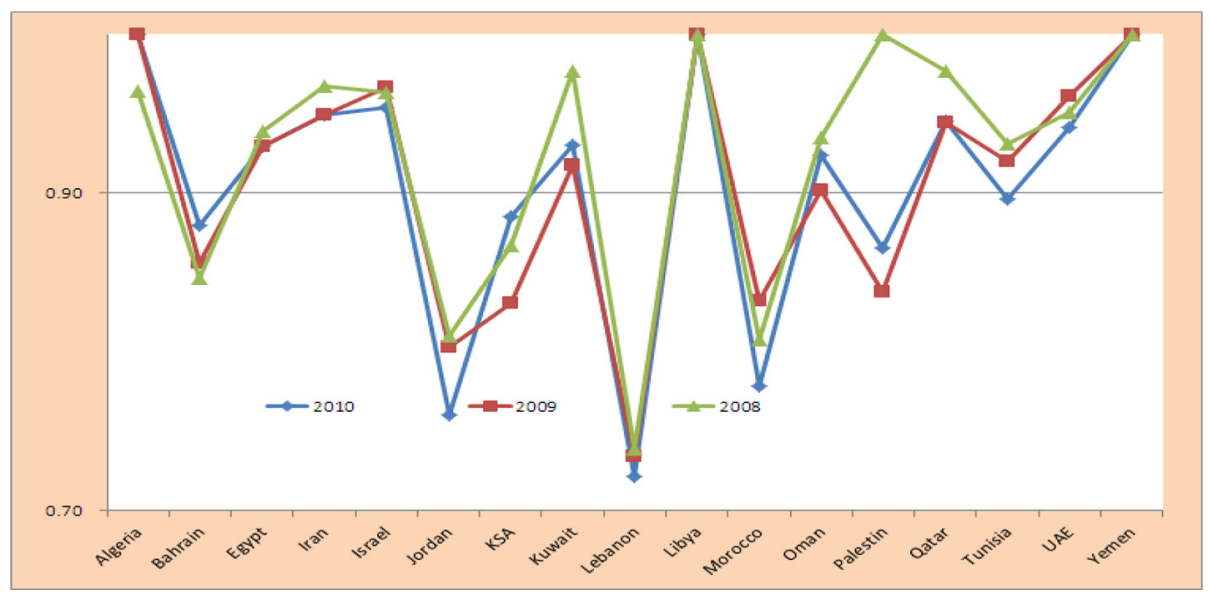

Figure 5.

Bank performance cross MENA countries (VRS output-oriented model)

\begin{tabular}{lccccrr}
\hline Methods & Accuracy $(\%)$ & Sensitivity $(\%)$ & Specificity $(\%)$ & AUC & AUC (S.E.) & \\
\hline CART & 75.50 & 52.63 & 89.36 & 0.7466 & 0.0408 & \\
RF-CART & 82.78 & 68.42 & 90.43 & 0.9293 & 0.0194 & Table V. \\
ANN & 68.21 & 61.40 & 72.34 & 0.6951 & 0.0439 & Performance of the \\
Bagging & 84.11 & 73.68 & 91.49 & 0.9221 & 0.0229 & six methods \\
CIT & 67.55 & 80.70 & 59.57 & 0.7077 & 0.0371 & 0.0306 \\
RF-CIT & 75.50 & 52.63 & 89.36 & 0.8516 & \\
\hline
\end{tabular}


IMEFM

12,2

\section{4}

Figure 6.

Performance based on ROC curves

\subsection{Critical variables to predict bank performance}

To identify the most critical environmental variables on bank efficiency and to investigate the interaction between efficiency score and the changes in the environmental variables Table VII reports the results.

Table VII lists the factors from the important of each variable based on RF and the significant variables based on linear regression. As Table VII, shows that both results agreed on the most important and significant variables: country, cost to income ratio and equity/net loans seem to be the most important factors in predicting bank performance, while interbank ratio and loan loss provision/net interest revenue seem to be the least important factors. This means that the performance and steady growth of the financial sector depend on an adequate regulatory framework. It is worth to note that these results are consistent with the findings of recent studies by Wanke et al. (2016), Li et al. (2017) and Sufian (2009) who found positive relationships between bank efficiency and equity to total assets ratio, $\mathrm{ROA}, \mathrm{ROE}$, loan loss reverse to gross loan and cost-to-income ratio.

Hence, the major concern of policymakers in countries with an inefficient banking sector need to investigate the reason for this inefficiency and learn from other countries with an efficient banking sector to improve and strengthen their financial sector. They need to understand the mechanisms of a healthy financial environment and help promote the health, safety and vitality of their banking sector in the coming years. The analysis also suggests that the decline in relative technical efficiency was attributed to the following many reasons such as cost-to-income ratio, equity-to-net loans ratio, equity-to-total assets ratio, loan loss reserve-to-gross loans ratio, net loan-to-deposit and short-term funding ratio and equity-toliabilities ratio. This suggests that strong and prompt policy actions are needed to address these variables and recapitalize bank assets and cost to be more efficient.

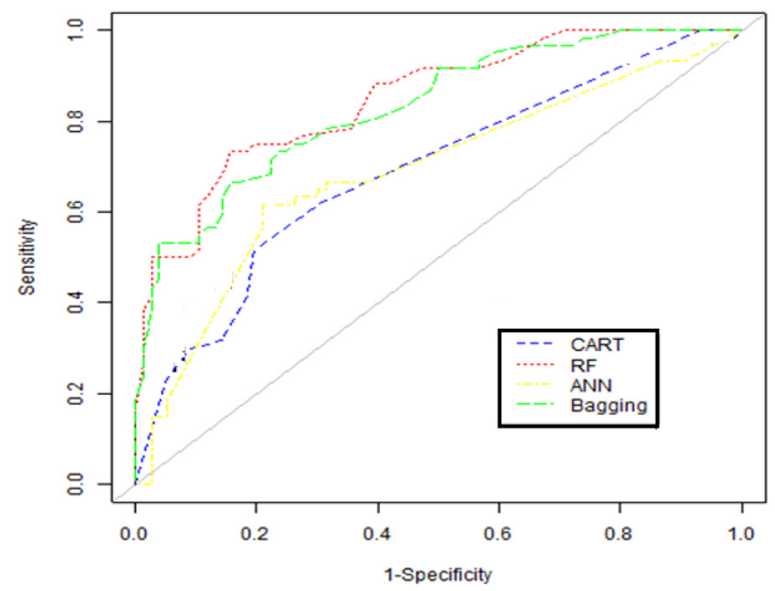

Table VI.

Performance of the seven methods

\begin{tabular}{lccc}
\hline Methods & Accuracy (\%) & AUC & AUC (S.E.) \\
\hline LR & 74.83 & 0.8186 & 0.0348 \\
RF-CART & 82.78 & 0.9293 & 0.0194 \\
\hline
\end{tabular}




\begin{tabular}{|c|c|c|c|}
\hline Variable & Variable importance & Linear regression* & Jata \\
\hline Country & 1.45 & $\begin{array}{l}\text { Net loan/deposit and short } \\
\text { term funding }\end{array}$ & analysis \\
\hline Cost to income ratio & 1.12 & Equity/net loans & \\
\hline Equity/net loans & 1.03 & Equity/tot assets & \\
\hline Equity/total assets & 0.99 & Equity/liabilities & \\
\hline $\begin{array}{l}\text { Loan loss reserve/gross } \\
\text { loans }\end{array}$ & 0.9 & Cost to income ratio & 185 \\
\hline $\begin{array}{l}\text { Net loan/deposit and short } \\
\text { term funding }\end{array}$ & 0.81 & $\begin{array}{l}\text { Return on average equity } \\
\text { (ROAE) }\end{array}$ & \\
\hline Equity/liabilities & 0.8 & $\begin{array}{l}\text { Loan loss reserve/gross } \\
\text { loans }\end{array}$ & \\
\hline Net loans/total assets & 0.79 & Cost to income ratio & \\
\hline $\begin{array}{l}\text { Return on avg. equity } \\
\text { (ROAE) }\end{array}$ & 0.76 & Country & \\
\hline Recurring earning power & 0.76 & & \\
\hline Net interest margin & 0.75 & & \\
\hline $\begin{array}{l}\text { Return on avg. assets } \\
\text { (ROAA) }\end{array}$ & 0.59 & & \\
\hline $\begin{array}{l}\text { Liquid assets/total deposit } \\
\text { and Borrowing }\end{array}$ & 0.59 & & \\
\hline Loan loss provision/net & 0.52 & & \\
\hline $\begin{array}{l}\text { interest revenue } \\
\text { Interbank ratio }\end{array}$ & 0.04 & & $\begin{array}{r}\text { Table VII. } \\
\text { Variable importance }\end{array}$ \\
\hline \multicolumn{3}{|c|}{ Note: *Significant variables based on linear regression analysis at $\alpha \leq 0.05$} & obtained by $R F$ \\
\hline
\end{tabular}

Take for example, the cost-to-income ratio is widely regarded as a yardstick when comparing productivity and efficiency of banks, a high cost-to-income ratio is equivalent to low productivity and low efficiency and vice versa (Burger and Moormann, 2008). Also, equity-to-net loans ratio is another important variable of bank efficiency that represent the percentage of the total assets that are financed by stockholders, as opposed to creditors. A low equity ratio will produce good results for stockholders as long as the company earns a rate of return on assets that is greater than the interest rate paid to creditors.

Furthermore, investors will gain more return from investing in MENA countries' banking sector if they invest their money in those countries whose banking sector is efficient. In addition, if bank managers want to open new branches in MENA countries, they are advised to open them in countries that have a healthy financial environment for the bank to be considered efficient.

\section{Conclusion}

Different statistical and data mining techniques have been used in DEA second stage to measure the impact of environmental variables on a DMU performance. Each method has its advantages and disadvantages. Most previous studies of bank performance that use the DEA second-stage approach have focused on how to explain the impact of an environmental variable on bank performance instead of predicting future bank performance. This study focused on comparing seven popular statistical and data mining techniques used in second DEA stage for bank performance to better predict bank performance in MENA countries. The techniques we used comprised CART, CIT, random forest based on CART (RF-CART), random forest based on CIT (RF-CIT) and bagging, as well as ANNs and LR. RFs and bagging have gained popularity in recent 
IMEFM

12,2

186

years due to their superior performance in a range of applications. However, these methods, particularly random forests based on CIT, have not been used widely to predict bank performance. We provided a comparison of performance considering several measures of prediction performance such as sensitivity, specificity, overall accuracy and the area under the ROC curve (AUC). Approximately, the seven methods showed adequate ability to model bank performance. However, the overall performance of random forests and bagging was superior. A key advantage of random forests is also the variables importance ranking. In our case, RF ranked "Country", "Cost to income ratio" and "Equity/Net loans" as the most important factors in predicting bank performance and "Interbank ratio" and "Loan loss provision/Net interest revenue" as the least important ones. We agree that any specific data may have different fits from different data mining techniques. In the context of bank performance prediction with a target variable (Efficiency) obtained from DEA-VRs (which is our case); RFs based on CART trees were powerful tools to predict bank performance in MENA countries. Therefore, they would be of a great benefit to practitioners and researchers in MENA countries who are interested in predicting bank performance.

The result shows that both RFs and bagging techniques are the best tools to predict bank performance using DEA-VRS model. Future research should target different data set and carefully analyze the role of their environmental and regulatory specifics in efficiency levels with other DEA models such as slack-based measure and network DEA, to predict the efficiency of DMUs. However, the availability of real data is challenging; thus, a study involving simulations of different scenarios could be an interesting topic to be explored. Furthermore, as data mining tools are sensitive to used data; hence, possible venues of future studies could also try to overcome some limitations of the current study by using other environmental variables other the one used in this study to test the robustness of RFs and bagging techniques in predicting performance.

\section{References}

Akin, A., Bayyurt, N. and Zaim, S. (2013), "Managerial and technical inefficiencies of foreign and domestic banks in Turkey during the 2008 global crisis", Emerging Markets Finance and Trade, Vol. 49 No. 3, pp. $48-63$.

Amirteimoori, A., Daneshiana, B., Kordrostamia, S. and Shahroodi, K. (2013), "Production planning in data envelopment analysis without explicit inputs", RAIRO - Operations Research, Vol. 47 No. 3, pp. 273-284.

Amirteimoori, A. and Emrouznejad, A. (2011), "Flexible measures in production process: a DEA-based approach", RAIRO - Operations Research, Vol. 45 No. 1, pp. 63-74.

Amirteimoori, A. and Yan, F. (2014), "A DEA model for two-stage parallel-series production processes", RAIRO - Operations Research, Vol. 48 No. 1, pp. 123-134.

Anouze, A.L. (2010), "Evaluating productive efficiency: Aomparative study of commercial banks in Gulf Countries", Unpublished $\mathrm{PhD}$ thesis, Aston Business School, Aston University.

Antipov, E. and Pokryshevskaya, E. (2012), "Mass appraisal of residential apartments: an application of random forest for valuation and a CART-based approach for model diagnostics", Expert Systems with Applications, Vol. 39 No. 2, pp. 1772-1778.

Ariff, M. and Can, L. (2008), "Cost and profit efficiency of Chinese banks: a non-parametric analysis", China Economic Review, Vol. 19 No. 2, pp. 260-273.

Assaf, A., Barros, C. and Matousek, R. (2011), "Technical efficiency in saudi banks", Expert Systems with Applications, Vol. 38, pp. 5781-5786. 
Azadeh, A., Saberi, M., Moghaddam, R. and Javanmardi, L. (2011), "An integrated data envelopment analysis-artificial neural network-rough set algoritm for assessment of personnel efficiency", Expert Systems with Applications, Vol. 38 No. 3, pp. 1364-1373.

Azen, R. and Budescu, D. (2003), "The dominance analysis approach for comparing predictors in multiple regression", Psychological Methods, Vol. 8 No. 2, pp. 129-148.

Banker, R., Charnes, A. and Cooper, W. (1984), "Some models for estimating technical and scale inefficiencies in data envelopment analysis", Management Science, Vol. 30 No. 9, pp. 1078-1092.

Berger, A. and Humphrey, D. (1997), "Efficiency of financial institutions: international survey and directions for future research", European Journal of Operational Research, Vol. 98 No. 2, pp. 175-212.

Bou-Hamad, I., Anouze, A.L. and Larocque, D. (2017), "An integrated approach of data envelopment analysis and boosted generalized linear mixed models for efficiency assessment", Annals of Operations Research, Vol. 253 No. 1, pp. 77-95.

Bou-Hamad, I., Larocque, D. and Ben-Ameur, H. (2011), "Discrete-time survival trees and forests with time-varying covariates: application to bankruptcy", Statistical Modelling: An International Journal, Vol. 11 No. 5, pp. 429-446.

Bou-Hamad, I., Larocque, D., Ben-Ameur, H., et al. (2009), "Discrete-time survival trees", Canadian Journal of Statistics, Vol. 37 No. 1, pp. 17-32.

Breiman, L. (1996), "Bagging predictors”, Machine Learning, Vol. 24 No. 2, pp. 123-140.

Breiman, L. (2001), “Random forests”, Machine Learning, Vol. 45 No. 1, pp. 5-32.

Breiman, L., Friedman, J., Olshen, R. and Stone, C. (1984), Classification and Regression Trees, Wadsworth International Group, Belmont, CA.

Burger, A. and Moormann, J. (2008), "Productivity in banks: myths and truths of the cost income ratio", Banks and Bank Systems, Vol. 3 No. 4, pp. 85-94.

Burki, A. and Niazi, G. (2010), "Impact of financial reforms on efficiency of state owned private and foreign banks in Pakistan", Applied Economics, Vol. 42 No. 24, pp. 3147-3160.

Castillo, E., Guijarro-Berdiñas, B., Fontenla-Romero, O. and Alonso-Betanzos, A. (2006), "A very fast learning method for neural networks based on sensitivity analysis", Journal of Machine Learning Research, Vol. 7, pp. 1159-1182.

Casu, B. and Molyneux, P. (2003), "A comparative study of efficiency in european banking", Applied Economics, Vol. 35 No. 17, pp. 1865-1876.

Chan, S., Karim, M., Burton, B. and Aktan, B. (2014), "Efficiency and risk in commercial banking: empirical evidence from East Asian countries", The European Journal of Finance, Vol. 20 No. 12, pp. 1114-1132.

Charnes, A., Cooper, W. and Rhodes, E. (1978), "Measuring the efficiency of decision making units", European Journal of Operational Research, Vol. 2 No. 6, pp. 429-444.

Chortareas, G., Girardone, C. and Ventouri, A. (2013), "Financial freedom and bank efficiency: evidence from the european union”, Journal of Banking and Finance, Vol. 37, pp. 1223-1231.

Chronopoulos, D., Girardone, C. and Nankervis, J. (2011), "Are there any cost and profit efficiency gains in financial conglomeration? Evidence from the accession countries", The European Journal of Finance, Vol. 17 No. 8, pp. 603-621.

Courville, T. and Thompson, B. (2001), "Use of structure coefficients in published multiple regression articles: is not enough", Educational and Psychological Measurement, Vol. 61 No. 2, pp. 229-248.

Elyasiani, E. and Wang, Y. (2012), "Bank holding company diversification and production efficiency", Applied Financial Economics, Vol. 22 No. 17, pp. 1409-1428.

Emrouznejad, A. and Anouze, A.L. (2010), "Data envelopment analysis with classification and regression tree: a case of banking efficiency”, Expert Systems, Vol. 27 No. 4, pp. 231-246.

Emrouznejad, A. and De Witte, K. (2010), "COOPER-framework: a unified process for non-parametric projects”, European Journal of Operational Research, Vol. 207 No. 3, pp. 1573-1586. 
IMEFM

12,2

Emrouznejad, A., Parker, B. and Tavares, G. (2008), "Evaluation of research in efficiency and productivity: a survey and analysis of the first 30 years of scholarly literature in DEA", Journal of Socio-Economic Planning Science, Vol. 42 No. 3, pp. 151-157.

Epure, M., Kerstens, K. and Prior, D. (2011), "Bank productivity and performance groups: a decomposition approach based upon the luenberger productivity indicator", European Journal of Operational Research, Vol. 211 No. 3, pp. 630-641.

Estelle, S., Johnson, A. and Ruggiero, J. (2010), "Three-stage DEA models for incorporating exogenous inputs", Computers and Operations Research, Vol. 37, pp. 1087-1090.

Fernandes, F., Stasinakis, C. and Bardarova, V. (2018), "Two-stage DEA-truncated regression: application in banking efficiency and financial development", Expert Systems with Applications, Vol. 96, pp. 284-301.

Fethi, M. and Pasiouras, F. (2010), "Assessing bank efficiency and performance with operational research and artificial intelligence techniques: a survey", European Journal of Operational Research, Vol. 204 No. 2, pp. 189-198.

Fiordelisi, F. and Molyneux, P. (2010), "Total factor productivity and shareholder returns in banking”, Omega, Vol. 38 No. 5, pp. 241-253.

Fried, H., Lovell, C., Schmidt, S. and Yaisawarng, S. (2002), "Accounting for environmental effects and statistical noise in data envelopment analysis", Joumal of Productivity Analysis, Vol. 17 Nos 1/2, pp. 157-174.

Gardener, E., Molyneux, P. and Nguyen-Linh, H. (2011), "Determinants of efficiency in South East Asian banking”, The Service Industries Journal, Vol. 31 No. 16, pp. 2693-2719.

Grömping, U. (2007), "Estimators of relative importance in linear regression based on variance decomposition", The American Statistician, Vol. 61 No. 2, pp. 139-147.

Hanafizadeh, P., Khedmatgozar, H., Emrouznejad, A. and Derakhshan, M. (2014), "Neural network DEA for measuring the efficiency of mutual funds", International Journal of Applied Decision Sciences, Vol. 7 No. 3, pp. 255-269.

Hermes, N. and Nhung, V. (2010), "The impact of financial liberalization on bank efficiency: evidence from latin america and asia", Applied Economics, Vol. 42 No. 26, pp. 3351-3365.

Hosmer, D. and Lemeshow, S. (2000), Applied Logistic Regression, Wiley, New York, NY.

Hothorn, T., Hornik, K., van de Wiel, M. and Zeileis, A. (2006a), "A lego system for conditional inference”, The American Statistician, Vol. 60 No. 3, pp. 257-263.

Hothorn, T., Hornik, K. and Zeileis, A. (2006b), "Unbiased recursive partitioning: a conditional inference framework", Journal of Computational and Graphical Statistics, Vol. 15 No. 3, pp. 651-674.

Hou, X., Wang, Q. and Zhang, Q. (2014), "Market structure, risk taking, and the efficiency of Chinese commercial banks", Emerging Markets Review, Vol. 20, pp. 75-88.

Johnson, J. and LeBreton, J. (2004), "History and use of relative importance indices in organizational research", Organizational Research Methods, Vol. 7 No. 3, pp. 238.

Kim, Y.S. (2006), "Toward a successful CRM: variable selection, sampling, and ensemble”, Decision Support Systems, Vol. 41 No. 2, pp. 542-553.

Lai, M.-C., Huang, H.-C. and Wang, W.-K. (2011), "Designing a knowledge-based system for benchmarking: a DEA approach", Knowledge-Based Systems, Vol. 24 No. 5, pp. 662-671.

LeBlanc, M. and Crowley, J. (1992), "Relative risk trees for censored survival data", Biometrics, Vol. 48 No. 2, pp. 411-425.

Li, Z., Crook, J. and Andreeva, G. (2017), "Dynamic prediction of financial distress using malmquist DEA”, Expert Systems with Applications, Vol. 80, pp. 94-106.

Ling, C.X., Huang, J. and Zhang, H. (2003), "AUC: a statistically consistent and more discriminating measure than accuracy", Proceedings of the International Joint Conferences on Artificial Intelligence, pp. 519-526.

Luo, D., Yao, S., Chen, J. and Wang, J. (2011), "World financial crisis and efficiency of Chinese commercial banks", The World Economy, Vol. 34 No. 5, pp. 805-825. 
Matthews, K. (2013), "Risk management and managerial efficiency in Chinese banks: a network DEA framework", Omega, Vol. 41 No. 2, pp. 207-215.

Mesa, R., Sánchez, H. and Sobrin, J. (2014), Main Determinants of Efficiency and Implications on Banking Concentration in the European Union. Revista de Contabilidad, Vol. 17, pp. 78-87.

Data
envelopment analysis

Miah, M. and Uddin, H. (2017), "Efficiency and stability: a comparative study between Islamic and conventional banks in GCC countries", Future Business Journal, Vol. 3 No. 2, pp. 172-185.

Morgan, J. and Sonquist, J. (1963), "Problems in the analysis of survey data and a proposal", Journal of the American Statistical Association, Vol. 58 No. 302, pp. 415-434.

Nguyen, T. (2018), "Diversification and bank efficiency in six ASEAN countries", Global Finance Journal, Vol. 37, pp. 57-78.

Pedhazur, E.J. (1997), Multiple Regression in Behavioral Research, Harcourt Brace, Fort Worth.

Ray, S. (1988), "Data envelopment analysis, nondiscretionary inputs and efficiency: an alternative interpretation”, Socio-Economic Planning Science, Vol. 22 No. 4, pp. 167-176.

Ray, S. (1991), "Resource-use efficiency in public schools: a study of Connecticut data", Management Science, Vol. 37 No. 12, pp. 1620-1628.

Rezvanian, R., Ariss, R. and Mehdian, S. (2011), "Cost efficiency, technological progress and productivity growth of Chinese banking pre- and post-WTO accession", Applied Financial Economics, Vol. 21 No. 7, pp. 437-454.

Rosman, R., Abd Wahab, N. and Zainol. Z., (2013), "Efficiency of Islamic banks during the financial crisis: an analysis of Middle Eastern and asian countries", Pacific-Basin Finance Journal, doi: 10.1016/j.pacfin.2013.11.00.

Rumelhart, D., Hinton, G. and William, R. (1986), "Learning representations of back-propagation errors", Nature, Vol. 323 No. 6088, pp. 533-536.

San, O., Theng, L. and Heng, T. (2011), "A comparison on efficiency of domestic and foreign banks in Malaysia: a DEA approach”, Business Management Dynamics, Vol. 1, pp. 33-49.

San-Jose, L., Retolaza, J. and Pruñonosa, J. (2014), "Efficiency in spanish banking: a multistakeholder approach analysis", Journal of International Financial Markets, Institutions and Money, Vol. 32, pp. 240-255.

Seol, H., Choi, J., Park, G. and Park, Y. (2007), "A framework for benchmarking service process using data envelopment analysis and decision tree", Expert Systems with Applications, Vol. 32 No. 2, pp. $432-440$.

Shawtari, F., Ariff, M. and Abdul Razak, S. (2015), "Efficiency assessment of banking sector in Yemen using data envelopment window analysis: a comparative analysis of islamic and conventional banks", Benchmarking: An International Journal, Vol. 22 No. 6, pp. 1115-1140.

Shmueli, G., Patel, N. and Bruce, P. (2010), Data Mining for Business Intelligence: Concepts, Techniques, and Applications in Microsoft Office Excel with XLMiner. (2nd Ed.), Wiley, NJ.

Shyu, J. and Chiang, T. (2012), "Measuring the true managerial efficiency of bank branches in Taiwan: a three-stage DEA analysis", Expert Systems with Applications, Vol. 39 No. 13, pp. 11494-11502.

Singh, P. and Thaker, K. (2016), "Dynamics of scale efficiency of indian banks: a deterministic frontier approach", The Journal of Developing Areas, Vol. 50 No. 3, pp. 437-457.

Staub, R., Souza, G. and Tabak, B. (2010), "Evolution of bank efficiency in Brazil: a DEA approach", European Journal of Operational Research, Vol. 202 No. 1, pp. 204-213.

Strobl, C., Boulesteix, A.-L., Zeileis, A. and Hothorn, T. (2007), "Bias in random forest variable importance measures: illustrations", Sources and a Solution, BMC Bioinformatics, Vol. 8, pp. 25.

Sufian, F. (2009), "Determinants of bank efficiency during unstable macroeconomic environment: empirical evidence from Malaysia”, Research in International Business and Finance, Vol. 23 No. 1, pp. 54-77.

Sufian, F. and Kamarudin, F. (2015), "Determinants of revenue efficiency of Islamic banks: empirical evidence from the Southeast Asian countries", International Journal of Islamic and Middle Eastern Finance and Management, Vol. 8 No. 1, pp. 36-63. 
IMEFM

12,2

Sun, J. and Li, H. (2008), "Data mining method for listed companies' financial distress prediction", Knowledge-Based Systems, Vol. 24, pp. 1-5.

Sutton, C. (2005), "Classification and regression trees, bagging, and boosting", Handbook of Statistics, Vol. 24, pp. 303-329.

Tana, Y. and Anchor, J. (2017), "The impacts of risk-taking behaviour and competition on technical efficiency: evidence from the chinese banking industry", Research in International Business and Finance, Vol. 41, pp. 90-104.

Tanna, S., Pasiouras, F. and Nnadi, M. (2011), "The effect of board size and composition on the efficiency of UK banks", Int. J. of the Economics of Business, Vol. 18 No. 3, pp. 441-462.

Thanassoulis, E. (2001), Introduction to the Theory and Application of Data Envelopment Analysis: A Foundation Text with Integrated Software, Kluwer Academic, MA.

Toloo, M., Zandi, A. and Emrouznejad, A. (2015), "Evaluation efficiency of large-scale data set with negative data: an artificial neural network approach", The Journal of Supercomputing, Vol. 71 No. 7, pp. 2397-2411.

Wanke, P., Azad, M. and Barros, C. (2016), "Predicting efficiency in malaysian Islamic banks: a twostage TOPSIS and neural networks approach", Research in International Business and Finance, Vol. 36, pp. 485-498.

Wanke, P., Barros, C. and Faria, J. (2015), "Financial distress drivers in Brazilian banks: a dynamic slacks approach”, European Journal of Operational Research, Vol. 240 No. 1, pp. 258-268.

Wu, T.-C. and Hsu, M.-F. (2019), "Credit risk assessment and decision making by a fusion approach. Knowledge-based systems", available at: http://dx.doi.org/10.1016/j.knosys.2012.04.025

Yadav, R. and Katib, M. (2015), Technical Efficiency of Malaysia's Development Financial Institutions: Application of Two-Stage DEA Analysis, Asian Social Science, Vol. 11, pp. 175-182.

Yang, C.-C. (2012), "Service, investment, and risk management performance in commercial banks", The Service Industries Journal, Vol. 32 No. 12, pp. 2005-2025.

Yeh, I. and Lien, C. (2009), "The comparisons of data mining techniques for the predictive accuracy of probability of default of credit card clients", Expert Systems with Applications, Vol. 36 No. 2, pp. 2473-2480.

Zha, Y., Liang, N., Wu, M. and Bian, Y. (2016), "Efficiency evaluation of banks in China: a dynamic twostage slacks-based measure approach", Omega, Vol. 60, pp. 60-72, available at: http://dx.doi.org/ 10.1016/j.omega.2014.12.008i

Zhang, T. and Matthews, K. (2012), "Efficiency convergence properties of Indonesian banks 1992-2007", Applied Financial Economics, Vol. 22 No. 17, pp. 1465-1478.

Zhu, D. (2010), "A hybrid approach for efficient ensembles”, Decision Support Systems, Vol. 48 No. 3, pp. 480-487.

\section{Further reading}

Alandejania, M. and Asutay, M. (2017), "Nonperforming loans in the GCC banking sectors: does the islamic finance matter?", Research in International Business and Finance, Vol. 42, pp. 832-854.

\section{Corresponding author}

Abdel Latef M. Anouze can be contacted at: a.anouz@qu.edu.qa

For instructions on how to order reprints of this article, please visit our website:

www.emeraldgrouppublishing.com/licensing/reprints.htm

Or contact us for further details: permissions@emeraldinsight.com 